\title{
A Master Class in Family Doctor Leadership: Evaluating an Innovative Program
}

David White, MD, CCFP; June C. Carroll, MD, CCFP; Sara Crann, PhD, MA; Marla Shapiro, CM, MDCM, CCFP, MHSc, FRCPC, NCMP; Cynthia Whitehead, MD, CCFP, MScCH, PhD; Risa Freeman, MD, CCFP, MEd; Richard H. Glazier, MD, MPH, CCFP; Danielle Martin, MD, CCFP, MPP; Michael Kidd, AM, FAHMS

BACKGROUND AND OBJECTIVES: In family medicine, leadership is critical for health care delivery, advancing curricula, research, and quality improvement. Systematic reviews of leadership development programs in health care identify limitations, calling for innovative designs and rigorous assessment. Our objective was to evaluate the impact of applying master class principles to leadership development in academic family medicine.

METHODS: We used mixed methods to assess the impact of an innovative master class program on $\mathbf{1 5}$ emerging leaders in a large academic department of family medicine. The program consisted of five sessions where family physician masters shared their wisdom, techniques, and feedback with promising leaders. Quantitative evaluation involved participants' ratings of each session's content and delivery using a 5-point Likert scale. We assessed postcourse semistructured interviews with participants qualitatively using descriptive thematic content analysis.

RESULTS: Individual sessions were highly evaluated, with a combined mean of $4.82 / 5$. Qualitative thematic analysis identified self-perceived increased effectiveness in leadership activities; increased confidence as a leader; increased motivation to be a leader; and perceptions of value from the program, contributing to what participants described as unexpected potential change within themselves. Themes related to effectiveness of the program were practical advice; networking; diverse topics; accessible speakers sharing personal stories; and small-group, informal, early-evening format.

CONCLUSIONS: Master class concepts can be adapted to leadership development in academic family medicine, with evidence of early positive impact on participants' self-perception of leadership skills and confidence. Further research is warranted to assess organizational impact and applicability to other settings.

(Fam Med. 2021;53(8):701-7.)

doi: 10.22454/FamMed.2021.512946
$\mathbf{L}$ eadership in family medicine (FM) is crucial for reshaping health care delivery, evolving curricula, expanding research, and focusing on quality improvement. ${ }^{1-4}$ The growing importance of leadership in medicine is reflected in its inclusion as a competence for trainees and practitioners. ${ }^{5-8}$ Leadership development programs have proliferated, yet systematic reviews find limited evidence of impact and call for rigor in identifying effective innovations. ${ }^{9-15}$

We postulated that a leadership development program modelled on music master classes could address an identified gap in supporting emerging leaders in our academic FM department. The defining

From the Department of Family \& Community Medicine, University of Toronto, Canada (Drs White, Carroll, Crann, Whitehead, Freeman, Glazier, Martin, Shapiro and Kidd); St. Michael's Hospital, Toronto, Canada (Dr Glazier); Women's College Hospital, Toronto, Canada (Drs Whitehead and Martin); North York General Hospital (Drs White, Shapiro, and Freeman); Wilson Centre, University Health Network, Faculty of Medicine, University of Toronto, Canada (Drs Whitehead and Freeman); University Health Network, Toronto, Canada (Dr Whitehead); Sinai Health System, Toronto, Canada (Dr Carroll); ICES, Toronto, Canada (Dr Glazier); College of Health and Medicine, Australian National University, Australia (Dr Kidd); Murdoch Children's Research Institute, The University of Melbourne, Australia (Dr Kidd); Southgate Institute for Health, Society and Equity, Flinders University, Australia (Dr Kidd). 
features of master classes are that accomplished students are invited or apply to perform in a group setting for a recognized master, who demonstrates and explains techniques and provides feedback and advice. ${ }^{16}$ Previous reports on master classes in health care include only some of these attributes. ${ }^{17-21}$

\section{Methods}

\section{Setting}

The Department of Family and Community Medicine (DFCM) at the University of Toronto is diverse and widely distributed, comprising over 1,700 faculty at 14 hospital-affiliated sites and multiple community practices.

\section{Intervention}

Our program is described in Figure 1 . The precourse assignment adapted the performance attribute of music master classes. In some sessions, the masters stimulated discussion and advice regarding participants' descriptions of their leadership challenges, but there was no grading or critique of individuals.

\section{Design and Analysis}

We used mixed methods to capture quantitative ratings of sessions and participants' experience. ${ }^{35}$ The quantitative evaluation was a questionnaire following each session. ${ }^{36}$ Participants rated content, process, and speakers on 10 attributes using a 5-point Likert scale.

For the qualitative evaluation, semistructured participant interviews were conducted 6 to 12 weeks following the last session by an independent qualitative researcher (S.C.) using a semistructured interview guide (Figure 2). Telephone interviews lasted 30-60 minutes, were audio-recorded, and transcribed verbatim. Data were initially organized and coded by S.C. in Dedoose, an online qualitative data software. Initial data organization mapped coded excerpts to interview questions with layered coding capturing more specific accounts or experiences. Following this, team members (S.C., J.C.C.,

Figure 1: The Master Class Program Description

The Model: The master class approach in music:

Master musicians share their wisdom, insights, techniques, coaching and feedback

- With aspiring performers selected on the basis on of their ability and promise

\section{The Program}

- Five 2-hour evening sessions over 10 weeks

- Each conducted by a master: faculty members who are internationally recognized leaders in areas relevant to academic family medicine

Participants

15 faculty members nominated by their site chiefs, based on two criteria:

- Demonstrated achievement in leadership

- Future potential growth as leaders

\section{Preparation}

1) Prereading: Two articles on family doctor leadership

2) Assignment: "Submit a one-page description of a leadership challenge you are facing in your current role"

\section{Purpose of the assignment}

- To engage participants in thinking about how they can apply learnings from the program

- To orient session leads to how participants conceptualize problems and potential solutions

- Not to specifically address or "solve" each issue

- To adapt the performance aspect of music master classes to leadership development

\begin{tabular}{|l|l|}
\hline Session Themes & Session Leads (Masters) \\
\hline Working with health services & Danielle Martin \\
\hline Working with medical education & Cynthia Whitehead \\
\hline Working with the media & Marla Shapiro \\
\hline Working with health research & Richard H. Glazier \\
\hline $\begin{array}{l}\text { Working with government, industry and not } \\
\text { for profit boards }\end{array}$ & Michael Kidd \\
\hline
\end{tabular}

Format:

- Highly interactive small group sessions

- A brief presentation from the "master" faculty member

- followed by or incorporating questions and discussion

- Time: 6:00 - 8:00 PM, dinner at 5:30 PM

- Setting: a comfortable meeting room on campus, away from clinical responsibilities 
Figure 2: Semistructured Interview Guide

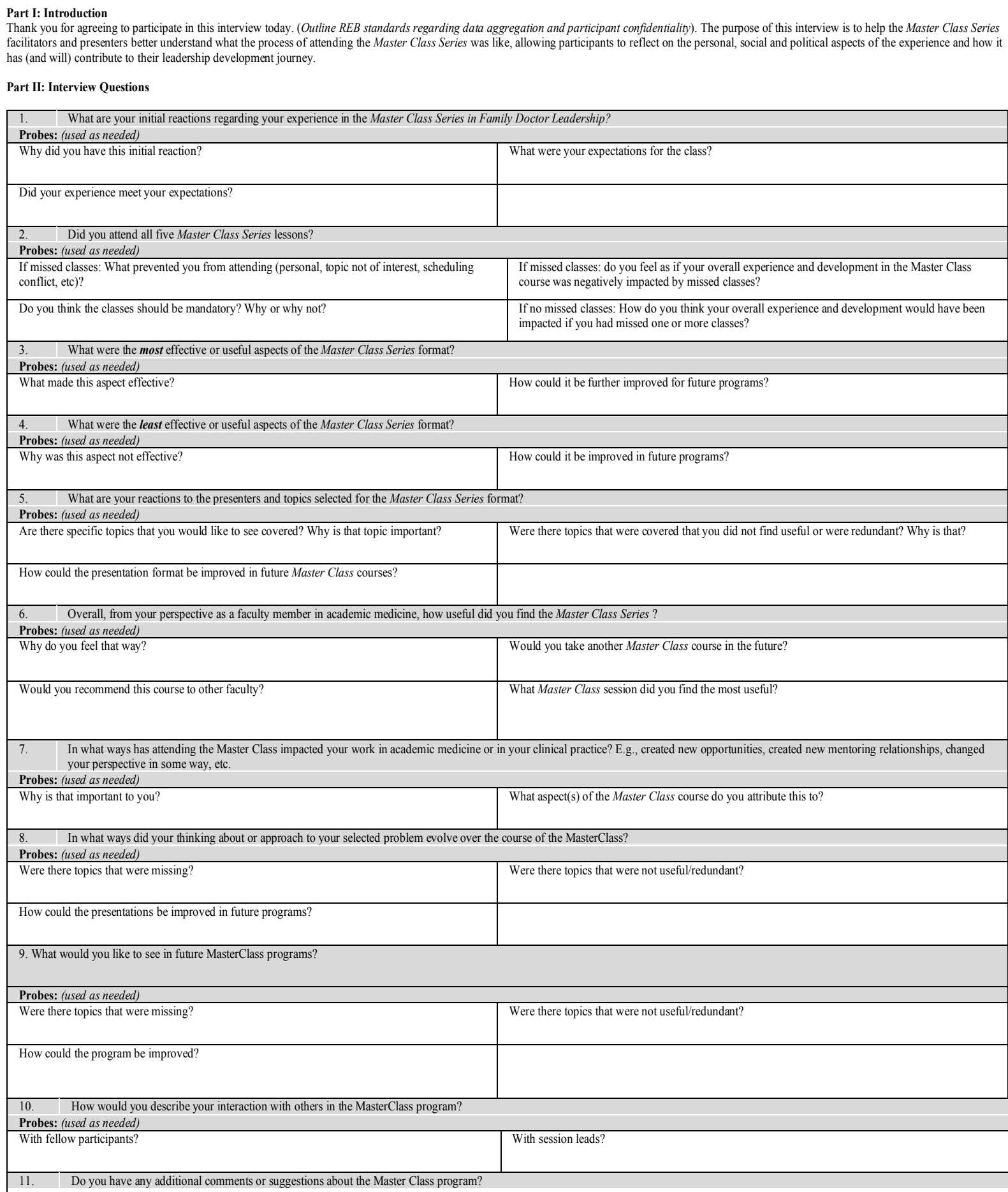

D.G.W.) independently reviewed the transcripts using descriptive thematic analysis. ${ }^{22}$ All team members then discussed and agreed upon themes. Any differences were resolved through discussion. Team members conducted a separate analysis of the participants' precourse assignments. Two researchers (J.C.C., D.G.W.) identified themes independently and resolved any differences through discussion.
The Research Ethics Board of the University of Toronto approved the study. 
Table 1: Themes Identified in Participants' Responses to the Precourse Assignment: Descriptions of Leadership Challenges They Were Facing (15 Participants)

\begin{tabular}{|l|c|}
\hline \multicolumn{1}{|c|}{ Leadership Challenge Theme } & $\begin{array}{c}\text { Number of Times } \\
\text { Identified* }\end{array}$ \\
\hline $\begin{array}{l}\text { Energizing a team/changing behavior } \\
\text { Engaging physicians in: } \\
\text { - Hospital committees } \\
\text { - Teaching } \\
\text { - Leadership }\end{array}$ & 6 \\
\hline Quality improvement projects & \\
\hline Change management: new direction or program & 1 \\
\hline Scheduling - IT and human resource challenges & 5 \\
\hline Project implementation & 1 \\
\hline Staff personnel conflict & 1 \\
\hline New financial/partnership agreement & 1 \\
\hline $\begin{array}{l}\text { Family medicine residency program } \\
\text { - Patient and supervisor challenges }\end{array}$ & 1 \\
\hline Delivering a patient care service & 3 \\
\hline Managing physician burnout/competing demands & 1 \\
\hline Changing clinical practice/quality improvement & 2 \\
\hline Communication & 2 \\
\hline
\end{tabular}

*More than one theme was identified in some leadership challenge descriptions.

Table 2: Overall Ratings of the Five Master Class Sessions*

\begin{tabular}{|l|c|c|}
\hline \multicolumn{1}{|c|}{ Item } & $\begin{array}{c}\text { Mean Rating } \\
\text { of Five } \\
\text { Sessions }\end{array}$ & $\begin{array}{c}\text { Standard } \\
\text { Deviation }\end{array}$ \\
\hline \multicolumn{1}{|c|}{ Program Content and Delivery } & & \\
\hline Was relevant & 4.74 & .44 \\
\hline Met my expectations & 4.77 & .52 \\
\hline Was well organized & 4.79 & .48 \\
\hline Met stated learning objectives & 4.83 & .45 \\
\hline $\begin{array}{l}\text { Disclosure of potential conflicts of interest was } \\
\text { clearly communicated }\end{array}$ & 4.91 & .34 \\
\hline $\begin{array}{l}\text { There were adequate opportunities to interact } \\
\text { with my peers }\end{array}$ & 4.80 & .48 \\
\hline $\begin{array}{l}\text { There were adequate opportunities to interact } \\
\text { with faculty }\end{array}$ & 4.88 & .37 \\
\hline $\begin{array}{l}\text { I will use the information I learned in my formal } \\
\text { and informal leadership roles. }\end{array}$ & 4.80 & .47 \\
\hline & & 4.80 \\
\hline $\begin{array}{l}\text { The master class was useful and enhanced my } \\
\text { knowledge of the subject }\end{array}$ & 4.83 & .42 \\
\hline The speaker was engaging and clear & $\mathbf{4 . 8 2}$ & .45 \\
\hline Overall & & \\
\hline
\end{tabular}

*There were 66 responses. With 15 participants and 5 sessions, the maximum possible number of responses is 75 , but some participants were unable to attend all sessions.

\section{Results}

There were 15 family physician participants, 13 women and 2 men. Themes in participants' precourse assignment are listed in Table 1.

\section{Quantitative Results}

Table 2 shows the course ratings for the session attributes. The mean rating for all five sessions was 4.82 out of 5 (SD 0.45).

\section{Qualitative Findings}

All 15 participants agreed to be contacted for postcourse interviews; 10 scheduled and completed interviews. Participants described the impact of the master class program and program attributes that were more or less effective. They described themselves as increasing in effectiveness, confidence, and motivation in leadership and that the program had contributed to unexpected potential changes within themselves. This could manifest as enhanced openness to new endeavours such as research or speaking to a reporter. Participants described changes that they had already incorporated, such as new skills, recognition of inherent abilities, and reinvigoration as a faculty member. Table 3 gives themes with representative quotes.

Participants identified some program attributes as both effective and ineffective. The interactive format was appreciated, but perceived by some as less transformative or exciting. Timing and location were considered problematic by those travelling greater distances, but dining together and being away from work were valued. Diverse topics and speakers were assets, but specific ones were identified in some interviews as less relevant.

\section{Discussion}

This evaluation of a leadership development program designed on the principles of music master classes shows evidence of early positive impact based on participants' self-evaluation. This program differs from previous reports of master classes in health care by incorporating key 
Table 3: Qualitative Themes

\begin{tabular}{|c|c|c|c|}
\hline \multirow{7}{*}{$\begin{array}{l}\text { Individual } \\
\text { Impact }\end{array}$} & Theme & Subtheme & Representative Quote \\
\hline & \multirow{2}{*}{$\begin{array}{l}\text { Self-perceived } \\
\text { increase in } \\
\text { effectiveness }\end{array}$} & $\begin{array}{l}\text { Enhanced self-awareness } \\
\text { and acceptance }\end{array}$ & $\begin{array}{l}\text { "... in terms of changing my thinking and being more open } \\
\text { to thinking about myself as a leader and thinking about } \\
\text { how I can improve and enhance my skills as a leader." }\end{array}$ \\
\hline & & Acquisition of specific skills & $\begin{array}{l}\text { "How to run an effective meeting...how to be an effective } \\
\text { participant...are things I have already implemented, and I } \\
\text { think will impact my current efficacy as a leader and also, } \\
\text { potentially, future career." }\end{array}$ \\
\hline & \multirow[t]{2}{*}{$\begin{array}{l}\text { Increased } \\
\text { confidence }\end{array}$} & As a leader (general) & $\begin{array}{l}\text { "I actually never thought of myself as a, quote/unquote, } \\
\text { "good leader"..I think when you are singled out by } \\
\text { someone, as it were, a mentor challenges you with a } \\
\text { new opportunity, it can sometimes provide, maybe, some } \\
\text { confidence or, maybe, just some space to think that you } \\
\text { would not normally allow yourself to do." }\end{array}$ \\
\hline & & $\begin{array}{l}\text { Leading in specific } \\
\text { endeavors }\end{array}$ & $\begin{array}{l}\text { "What I really do feel that I'm more comfortable in doing } \\
\text { is pushing people, and gently reminding people, or asking } \\
\text { people why they didn't attend a meeting." }\end{array}$ \\
\hline & $\begin{array}{l}\text { Increased } \\
\text { motivation and } \\
\text { opportunities }\end{array}$ & & $\begin{array}{l}\text { "I thought that the speakers were fantastic, and the group } \\
\text { was really motivating to be a part of." }\end{array}$ \\
\hline & $\begin{array}{l}\text { Perception of } \\
\text { value, possibly } \\
\text { leading to change }\end{array}$ & Unexpected value & $\begin{array}{l}\text { "I probably might be more inclined to take on something } \\
\text { that I may have shied away from in the past." }\end{array}$ \\
\hline \multirow{10}{*}{$\begin{array}{c}\text { Program } \\
\text { Attributes }\end{array}$} & \multirow{6}{*}{$\begin{array}{l}\text { Effective } \\
\text { attributes }\end{array}$} & $\begin{array}{l}\text { Practical advice from } \\
\text { experts }\end{array}$ & $\begin{array}{l}\text { "That's what a master class should be actually. It's really } \\
\text { getting information from people who have worked in } \\
\text { this field for a long time and just picking their brain for } \\
\text { important little details." }\end{array}$ \\
\hline & & Networking & $\begin{array}{l}\text { "I think it was really nice to network with other people } \\
\text { who are current leaders in the department, and who are } \\
\text { doing various, or leading various initiatives, again, in very } \\
\text { different disciplines within the field of family medicine." }\end{array}$ \\
\hline & & Precourse assignment & $\begin{array}{l}\text { "... it made it really feel like it's something that is quite } \\
\text { relevant to the leadership work that I was doing." }\end{array}$ \\
\hline & & $\begin{array}{l}\text { Speakers sharing personal } \\
\text { experiences }\end{array}$ & $\begin{array}{l}\text { "She talked a lot about her own experiences, and where } \\
\text { she came from, and also being imperfect and vulnerable at } \\
\text { times, but at the same time, really being strong enough to } \\
\text { face the challenges and solve the challenges." }\end{array}$ \\
\hline & & Interactive format & $\begin{array}{l}\text { “... they're not talking down to us. It was a much more } \\
\text { collegial conversation, which I think was good and } \\
\text { essential." }\end{array}$ \\
\hline & & $\begin{array}{l}\text { Diverse topics and } \\
\text { speakers }\end{array}$ & $\begin{array}{l}\text { "I got to really have a sense of the areas that one could } \\
\text { look at in terms of developing your own leadership, and } \\
\text { that there isn't just one formula or one way to do it." }\end{array}$ \\
\hline & \multirow{4}{*}{$\begin{array}{l}\text { Less effective } \\
\text { attributes }\end{array}$} & Interactive format & $\begin{array}{l}\text { "I would say [the program] was more on the, well, that was } \\
\text { interesting and something to think about, as opposed to, } \\
\text { wow, I'm going to go out and do that and change my life." }\end{array}$ \\
\hline & & Specific topics & "It [the topic] was probably less relevant to me." \\
\hline & & Time & $\begin{array}{l}\text { “...that time of the night, I think 6:30 to 8:30, we've all } \\
\text { worked long days." }\end{array}$ \\
\hline & & Location & “...one day it took me almost a half an hour just to travel." \\
\hline
\end{tabular}


defining characteristics: course leaders who are recognized masters, participants selected on demonstrated ability, a performance consisting of a precourse assignment, and a highly interactive format. ${ }^{17-21}$

Qualitative findings indicate successful incorporation of qualities that Souba identified as crucial for building leadership capacity: "ingredients that catalyze and enhance human connectivity, augment social capital, and activate leadership." ${ }^{33}$ Increased confidence, motivation, and selfawareness contribute to leadership activation. The opportunity to form new relationships with colleagues and potential mentors represents a significant benefit for a large, widely dispersed academic enterprise. ${ }^{33}$

Our findings align with Steinert's review of faculty development initiatives to promote leadership in medical education. ${ }^{12}$ These include high levels of satisfaction, greater awareness of personal strengths and limitations, increased motivation, confidence and networking, gains in knowledge and skills, and increased awareness of leadership roles. Systematic reviews identified the reliance on lectures and didactic methods as a weakness of physician leadership development programs. ${ }^{11,13}$ The interactive format of the master class addresses this concern.

The selection process incorporated a key recommendation from the Leadership Development Task Force of the Council of Academic Family Medicine, stating:

In developing the leadership pipeline, current leaders should look to colleagues, including junior colleagues, who may not have selfidentified as leaders but who have demonstrated leadership potential.

Study limitations include studying a small cohort at a single institution, lack of a control group, short follow-up time, and no assessment of organizational impact. Pre/post comparison is commonly employed for course evaluation; we chose qualitative methods to gain in-depth understanding of the meaningful and useful aspects of the program that contributed to growth and change. Although interviews could be scheduled with only 10 of 15 participants, the qualitative data is detailed, with important recurring themes evident in the descriptive thematic analysis. The precourse assignment is a limited adaptation of the performance attribute of master classes. Ericsson states that rigorous measurement of superior performance in medicine is difficult but possible, yet none of his examples address leadership performance. ${ }^{24,25}$ Enhancing the performative element remains a challenge and opportunity for further development.

An unexpected finding was the 13 to 2 ratio of female to male participants, significantly greater than the departmental ratio of 52:48. Criteria for selecting participants included no reference to gender, and 10 of the 15 nominating chiefs were men. Continuing the program will determine if this occurrence was random. Nevertheless, this group represents a cohort of emerging leaders with potential to redress the gender imbalance among senior roles.

Further research is needed to assess the longer-term impact on participants and the organization. Although not explicitly modelled after master classes, leadership development programs in medicine often incorporate similar elements. Intentional application of master class principles has the potential to enhance existing programs. Evaluating virtual delivery is relevant for broadening the scope and accessibility of this approach.

\section{Conclusion}

Master class principles can be adapted to leadership development in academic FM, with qualitative evidence of early positive impact based on participant self-assessment.

FINANCIAL SUPPORT: This study was supported by an Art of the Possible educational grant from the Department of Family \& Community Medicine, University of Toronto.
PRESENTATIONS: This research has been previously presented as follows:

White DG, Glazier R, Martin D, Shapiro M, Whitehead C, Carroll J, Freeman R, Crann S, Kidd M. The Master Class Series in Family Doctor Leadership: Evaluation of a new approach to leadership development (poster and oral presentation). Leaders in Healthcare 2019. November 5-6, 2019. Birmingham, England, UK.

White DG, Glazier R, Martin D, Shapiro M, Whitehead C, Carroll J, Freeman R, Crann S, Kidd M. The Master Class Series in Family Doctor Leadership: Evaluation of a new approach to leadership development (poster presentation). Family Medicine Forum 2019, College of Family Physicians of Canada. October 30, 2019. Vancouver, BC, Canada.

White DG, Glazier R, Martin D, Shapiro M, Whitehead C, Carroll J, Freeman R, Crann S, Kidd M. Evaluating a Master Class in Family Doctor Leadership: Completed Research (oral presentation). November 20, 2020. North American Primary Care Research Group Virtual Conference.

CORRESPONDING AUTHOR: Address correspondence to Dr David White, 500 University Avenue, 5th Floor, Toronto, Ontario M5G 1V7. 416-978-6473. david.white@utoronto.ca.

\section{References}

1. Wender R, Borkan J, Davis A; Association Of Departments Of Family Medicine. A pivotal time for family medicine leadership development. Ann Fam Med. 2011;9(2):182. doi:10.1370/afm.1236

2. Roberts RG, Snape PS, Burke K. Task Force Report 5. Report of the Task Force on Family Medicine's Role in Shaping the Future Healthcare Delivery System. Ann Fam Med. 2004;2(suppl 1):S88-S99. doi:10.1370/afm.138

3. Phillips RL Jr, Brundgardt S, Lesko SE, et al. The future role of the family physician in the United States: a rigorous exercise in definition. Ann Fam Med. 2014;12(3):250-255. doi:10.1370/afm.1651

4. Newton WP, DuBard CA. Shaping the future of academic health centers: the potential contributions of departments of family medicine. Ann Fam Med. 2006;4(suppl 1):S2-S11. doi:10.1370/ afm.587

5. Neeley SM, Clyne B, Resnick-Ault D. The state of leadership education in US medical schools: results of a national survey. Med Educ Online. 2017;22(1):1301697. doi:10.1080/10872981.201 7.1301697

6. Shaw E, Oandasan I, Fowler N. A competency framework for family physicians across the continuum. Mississauga, ON: College of Family Physicians of Canada; 2017.

7. Accreditation Council for Graduate Medical Education, (ACGME). Family Medicine Milestones. 2nd ed. Chicago: ACGME; 2019. https://www.acgme.org/Portals/0/PDFs/ Milestones/FamilyMedicineMilestones. pdf?ver=2020-09-01-150203-400. Accessed April 9, 2021 
8. NHS Institute for Innovation and Improvement and Academy of Medical Royal Colleges. Medical Leadership Competency Framework. 3rd ed. Coventry, UK: NHS Institute for Innovation and Improvement; 2010.

9. Straus SE, Soobiah C, Levinson W. The impact of leadership training programs on physicians in academic medical centers: a systematic review. Acad Med. 2013;88(5):710-723. doi:10.1097/ACM.0b013e31828af493

10. Seidman G, Pascal L, McDonough J. What benefits do healthcare organisations receive from leadership and management development programmes? A systematic review of the evidence. BMJ Leader. 2020;4(1):21-36. doi:10.1136/leader-2019-000141

11. Moore Simas TA, Cain JM, Milner RJ, et al. A Systematic Review of Development Programs Designed to Address Leadership in Academic Health Center Faculty. J Contin Educ Health Prof. 2019;39(1):42-48. doi:10.1097/ CEH.0000000000000229

12. Steinert Y, Naismith L, Mann K. Faculty development initiatives designed to promote leadership in medical education. A BEME systematic review: BEME Guide No. 19. Med Teach. 2012;34(6):483-503. doi:10.3109/014215 9X.2012.680937

13. Frich JC, Brewster AL, Cherlin EJ, Bradley $\mathrm{EH}$. Leadership development programs for physicians: a systematic review. J Gen Intern Med. 2015;30(5):656-674. doi:10.1007/s11606014-3141-1

14. Lucas R, Goldman EF, Scott AR, Dandar V. Leadership Development Programs at Academic Health Centers: Results of a National Survey. Acad Med. 2018;93(2):229-236. doi:10.1097/ACM.0000000000001813
15. Onyura B, Crann S, Tannenbaum D, Whittaker MK, Murdoch S, Freeman R. Is postgraduate leadership education a match for the wicked problems of health systems leadership? A critical systematic review. Perspect Med Educ. 2019;8(3):133-142. doi:10.1007/s40037-019 0517-2

16. Hanken IM. Teaching and Learning Music Performance: The Master Class. Finnish Journal of Music Education. 2008;11(1-2):26-36.

17. Toh CH, Strivens J, Guenova M, Modok S. A master class for European hematology. Haematologica. 2014;99(6):949-951. doi:10.3324/ haematol.2014.107540

18. Voll J, Bragg D, Maxwell-Armstrong C. Master class in administration skills - An innovative learning experience for future foundation doctors. Int J Surg. 2013;11(8):699. doi:10.1016/j. ijsu.2013.06.599

19. Turner AM, Facelli JC, Jaspers M, et al. Solving Interoperability in Translational Health Perspectives of Students from the International Partnership in Health Informatics Education (IPHIE) 2016 Master Class. Appl Clin Inform. 2017;8(2):651-659. doi:10.4338/ ACI-2017-01-CR-0012

20. Duffield C. A Master Class for nursing unit managers: an Australian example. J Nurs Manag. 2005;13(1):68-73. doi:10.1111/j.13652834.2004.00489.x

21. Webster M, Remedios L. Making the student the master in the master class. Physiotherapy. 2015;101:e1272-e1273. doi:10.1016/j physio.2015.03.1182

22. Braun V, Clarke V. Using thematic analysis in psychology. Qualitative Research in Psychology. 2006; 3(2):77 101, doi:10.1191/1478088706qp063oa
23. Souba WW. New ways of understanding and accomplishing leadership in academic medicine. J Surg Res. 2004;117(2):177-186. doi:10.1016/j. jss.2004.01.020

24. Ericsson KA. Acquisition and maintenance of medical expertise: a perspective from the expert-performance approach with deliberate practice. Acad Med. 2015;90(11):1471-1486. doi:10.1097/ACM.0000000000000939

25. Ericsson KA. Deliberate Practice and the Acquisition and Maintenance of Expert Performance in Medicine and Related Domains. Academic Medicine.Research in Medical Education Proceedings of the FortyThird Annual Conference November 7-10. 2004;79(10(Supplement):S70,S81, October 2004. doi:10.1097/00001888-200410001-00022 